\title{
A new genus of Nanaloricidae (Loricifera) from deep-sea sediments of volcanic origin in the Kilinailau Trench north of Papua New Guinea
}

Received: 26 March 2003 / Revised: 15 August 2003 / Accepted: 13 October 2003 / Published online: 28 November 2003 (C) Springer-Verlag and AWI 2003

\begin{abstract}
A new genus and species of Nanaloricidae (Loricifera), Phoeniciloricus simplidigitatus, is described inhabiting fine sand covered by a layer of volcanic ash at a water depth of $1,813 \mathrm{~m}$ in the New Ireland Basin near the Kilinailau Trench (north of Papua New Guinea). The described specimen is a postlarva enclosed in a larval exuvium. This is the first report of a species belonging to the Nanaloricidae from the deep sea. This occurrence is surprising, because Nanaloricidae are typical inhabitants of coarse sands in the intertidal or littoral zone. Preference for these shallow water habitats is reflected in many morphological features which characterize the Nanaloricidae, and are not normally found in Loricifera inhabiting fine-grained, clayish, deep-sea bottoms. The postlarva of the new species is characterized by a long narrow mouth tube, an urn-shaped lorica divided into ten plates, and 13 small lorica spikes. Distinguishing features of the Higgins-larva include short spinose toes lacking mucros but having small and slightly enlarged bases, short scalids on the introvert, many thoracic plates arranged in 6-8 rows, numerous small papillate flosculi in the collar and caudal regions, and three pairs of filiform, short locomotory appendages on the ventral side. Some features of the new species, especially of the Higgins-larva, are discussed as adaptations to the deep-sea environment.
\end{abstract}

Keywords Meiofauna $\cdot$ Loricifera $\cdot$ Deep sea Zoogeography · Expedition SO-133 EDISON II

Communicated by R.M. Kristensen

G. Gad (®)

AG Zoosystematik und Morphologie,

Fakultät V (für Mathematik und Naturwissenschaften),

Institut für Biologie und Umweltwissenschaften,

Carl von Ossietzky Universität Oldenburg,

26111 Oldenburg, Germany

e-mail: gunnar.gad@mail.uni-oldenburg.de

Tel.: +49-441-7983367

Fax: +49-441-7983162

\section{Introduction}

Adult Loricifera are bilaterally symmetrical interstitial invertebrates around $250 \mu \mathrm{m}$ long (Kristensen 1991a). The body of the adult is divided into a mouth cone, an eversible introvert densely covered with rows of scalids, a thorax with a neck region bearing basal plates and trichoscalids, and an abdominal region armoured with a lorica (Kristensen 2003). The lorica of Nanaloricidae consists of six or more heavily sclerotized plates with spikes at their anterior rim (Kristensen 1983). Their Higgins-larvae have similar body regions to the adults but clearly differ morphologically. The body of the larva is composed of a simpler mouth cone, an introvert covered with a lower number of short and more hook-like scalids, a collar as an intermediate region between introvert and thorax, a long and flexible thorax with transverse rows of plates, and an abdomen with a weakly developed lorica (Kristensen 1991a, 2003). The latter is equipped ventrally with grasping appendages and caudally with long toes for grasping or locomotion (Kristensen 1991a). Some Loriciferan taxa have complex life cycles (Kristensen and Brooke 2002). Sexes are separate and show a more or less pronounced sexual dimorphism in the structure of the clavoscalids and the copulatory spicule of males. Apart from the larval stages, a juvenile or postlarval stage occurs in the life cycle of Nanaloricidae (Kristensen 1991a).

The Loricifera is a poorly known meiofauna taxon inhabiting the well-oxygenated uppermost layers of the sediment (Higgins and Kristensen 1988). Loricifera have been found worldwide at depths from $7 \mathrm{~m}$ to $8,300 \mathrm{~m}$, i.e. in the subtidal zone as well as in the deep sea (Todaro and Kristensen 1998). Since their first description in 1983, only 11 species have been recorded in two families and three genera (Kristensen 2003). The first species described was Nanaloricus mysticus Kristensen, 1983, as the representative species of the Nanaloricidae, which was discovered in intertidal shell-gravel near the coast of Roscoff, France (Kristensen 1983). The second species of Nanaloricidae, Nanaloricus khaitatus Todaro and Kris- 
tensen, 1998 was found in a similar interstitial habitat in the Mediterranean Sea (Todaro and Kristensen 1998). There are only a few reports of Loricifera from the deep sea (Soetaert et al. 1984; Hubbard et al. 1988; Kristensen and Shirayama 1988). In fact, the first, and to date only, species discovered in the deep sea belongs to the second family of Loricifera, the Pliciloricidae. Pliciloricus hadalis Kristensen and Shirayama, 1988 was found inhabiting red clay $8,260 \mathrm{~m}$ deep in the Izu-Ogasawara Trench of the western Pacific (Kristensen and Shirayama 1988). The new species described here is the first report of a Nanaloricidae from the deep sea and from sediments influenced by volcanic and hydrothermal activity. This occurrence seems to be an exception, because Nanaloricidae have been assumed to prefer shallow water habitats (Gad 2003; Kristensen and Gad 2003). This is reflected in many morphological features which characterize the Nanaloricidae and which are normally not found in Loricifera inhabiting fine-grained, clayish, deep-sea bottoms.

Hydrothermalism is limited to restricted areas of tectonic activity throughout the deep-sea floors. In contrast to the well-known and intensively investigated macrofaunal and bacterial communities of these extreme biotopes, virtually nothing is known about the meiofauna of hydrothermal vents, nor the sediments influenced by them (Grassle 1986; Giere 1993). Early studies dealt with the structure of nematode communities around hydrothermal vents, as compared to communities from adjacent oxic deep-sea sediments or from the shallow, reduced, anoxic sediments of eutrophic bottoms (Vanreusel et al. 1997). Biological investigations during the cruise SO-133 EDISON to the submarine volcanoes of the New Ireland Basin concentrated on the study of the benthic fauna composition at and near hot vents (Herzig 1998).

\section{Methods}

Samples were taken during expedition SO-133 EDISON of the R/V 'Sonne' in 1998 around a fracture zone with neighbouring hydrothermal vents at the New Ireland Basin north of Papua New Guinea (see map, Fig. 1) in the Pacific Ocean (Herzig 1998).

The qualitative subsample yielding the species described here was sample number $63 \mathrm{GKG}\left(02^{\circ} 23^{\prime} 99^{\prime \prime} \mathrm{N} 152^{\circ} 50^{\prime} 83^{\prime \prime} \mathrm{E}\right)$ which had a volume of $160 \mathrm{~cm}^{3}$ and was taken using a great box corer (GKG) at $1,813 \mathrm{~m}$ depth to the north of Lihir Island, near the Kilinailau Trench, an inactive subduction zone (Herzig 1998). Sediments from sample 63 GKG are grey and brown medium sand covered by a 2$\mathrm{cm}$-thick layer of freshly erupted volcanic ash mixed with a few Foraminifera shells and tiny basaltic pepperites.

The sediment, together with the supernatant water, was fixed and preserved in $4 \%$ buffered formalin. The sediment was washed out later and filtered through a $40 \mu \mathrm{m}$ mesh. The meiofauna was extracted using the differential flotation method with the colloidal silica gel Levasil (density 1,299 $\mathrm{g} / \mathrm{ml}$, concentration $40 \%$, Bayer, Leverkusen, Germany), and the sample was centrifuged at $4,000 \mathrm{rpm}$. The sorted loriciferans were placed in $70 \%$ ethanol medium, later transferred to glycerol and mounted in glycerinparaffin-beewax preparations (adapted from Higgins and Thiel 1988), sealed with Glyceel (recipe after Brown 1997).

The microscopic investigation was carried out using a Leica interference-microscope (DMLB with UCA condenser, IC prism and additional magnification $\times 1.5$ and $\times 2$, Leica microsystems, Vienna, Austria). Illustrations were made with the aid of a drawing
Fig. 1 Regional map of the New Ireland Basin with the Kilinailau Trench and station number 63 (Herzig 1998)

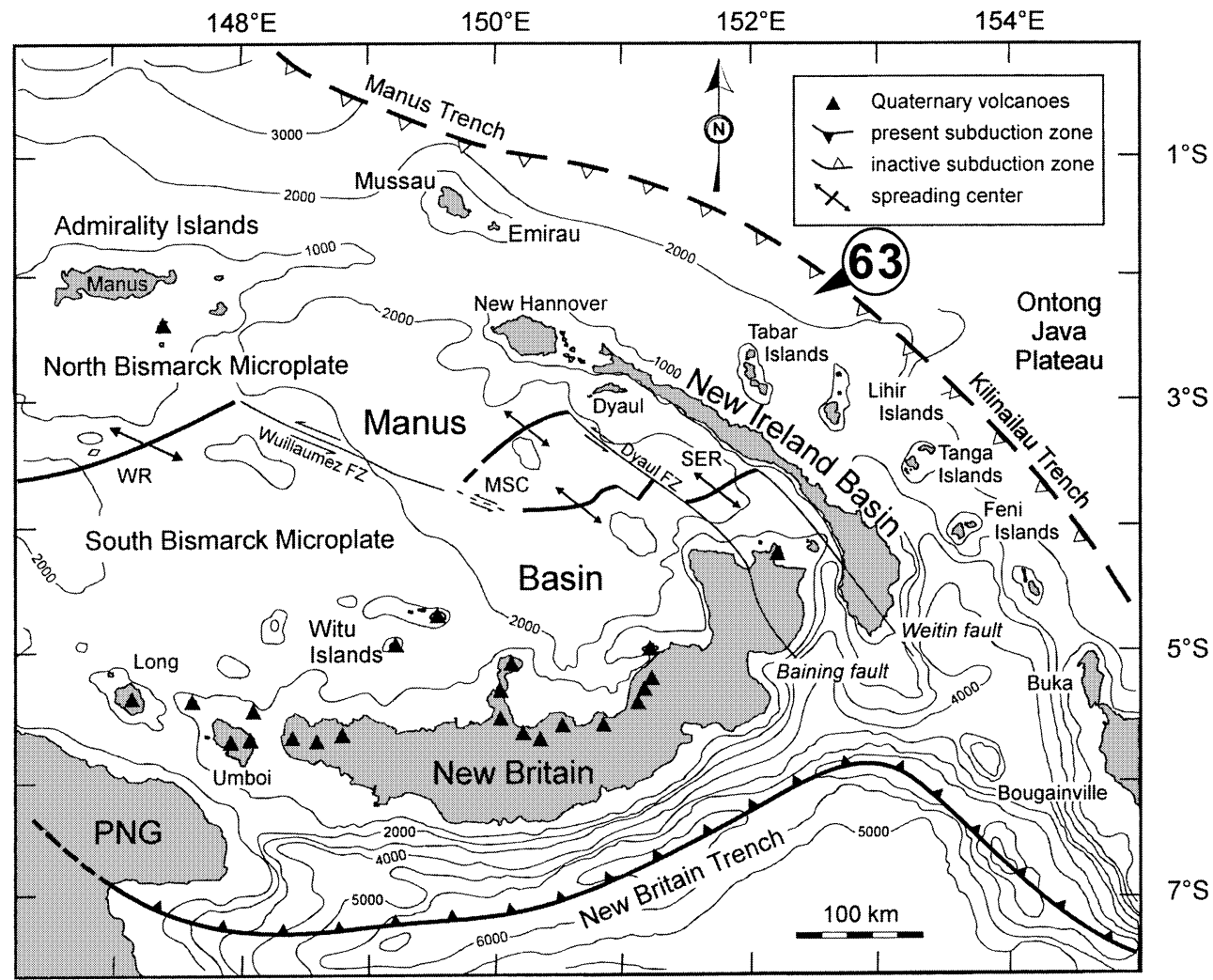


tube (mirror technique and macro-apparatus FS25PE, Leica). Photographs were taken using a computerised digital camera ColorView-imaging-system (Soft Imaging System, Münster, Germany) system adapted for the DM RXA microscope. The species was differentiated morphologically. The descriptive terminology is adapted from Higgins and Kristensen (1986). The type material has been deposited in the type collection of the AG Zoosystematik und Morphologie of the Carl von Ossietzky University Oldenburg.

\section{Results}

Phoeniciloricus simplidigitatus gen. et sp. nov.

\section{Genus diagnosis of Higgins-larva}

Last instar larva smaller than postlarva; clavoscalids spinose, short, divided into three segments; spinoscalids short, also spinose or weakly modified into hooks; thorax divided into six transverse rows of thoracic plates, dorsally into two additional subrows, plates folded transversally in a unique manner; collar region slightly developed, consisting of many small plates and two big ventral closing plates; three short, filiform pairs of appendages between thorax and lorica; abdominal lorica less armoured and defined by 18 irregular primary longitudinal ridges; cuticle of trunk with honeycomb ultrasculpture; caudal toes modestly long, spinose and with simple, modestly enlarged bases without any kind of mucro, spine-tips of toes strongly arched basally with an inner, large, single pore; trunk with numerous papillate flosculi, concentrated on the collar plates and at the caudal end; tiny anal cone situated on a small terminal anal field composed of 13 small anal plates; anal plates dorsally with three small papillate flosculi and a pair of tiny posteroterminal setae dorsally; additionally two modestly long pairs of sensory setae in the caudal region.

\section{Genus diagnosis of postlarva}

Postlarva of small size, with a short, well-defined mouth cone bearing eight elevated external furcae of equal length, and with an extremely long, narrow, nonretractable mouth tube distally; buccal tube long and narrow with striae flexible and telescopically retractable distally; internal prepharyngeal armature small, but with short manubrium; large muscular and round pharyngeal bulb; internal pharyngeal layer strongly sclerotized with five transversal rows of small placoids; spinose clavoscalids broad; two types of spinoscalids in the second row: one longer and spinose, the other smaller and feather-like; spinoscalids in the third row each with double tips; sixth row of scalids is missing; scalids in the eighth row like small beaks; two types of short trichoscalids, single and double, the double trichoscalids separated basally; lorica consisting of ten plates, with a honeycomb ultrasculpture on its surface, middorsal plate flanked by two narrow longitudinal dorsolateral plates, inner lateral margins of middorsal plate folded upwards and covering (together with the inner margins of the neighbouring plates) the remaining portion of the middorsal plate; elements of laterocaudal articulation (ridges and sockets) of lorical plates in caudal position; anterior rim of lorica with 13 very short spikes; gland ducts of lorica spikes with small reservoirs; 18 welldeveloped papillate flosculi in posterior half of lorica; anal cone located more ventrally, covered by a large, shield-like, dorsal anal plate.

\section{Composition}

Phylum Loricifera Kristensen, 1983

Family Nanaloricidae Kristensen, 1983

Type genus Nanaloricus Kristensen, 1983

Type species Nanaloricus mysticus Kristensen, 1983

Phoeniciloricus gen. nov.

Type species Phoeniciloricus simplidigitatus sp. nov.

\section{Etymology}

The genus name refers to the magic bird the phoenix (lat. phoenix), of unsurpassed beauty, from Egyptian mythology which lived a lonely life and then consumed itself by fire to later rise rejuvenated from its ashes. This is an allusion to the sediments covered with layers of volcanic ash in which the new species was found; loricus from lat. lorica meaning corset.

\section{Phoeniciloricus simplidigitatus sp. nov.}

Type material: the holotype is a last instar Higgins-larva containing a postlarva (mounted on slide UNI-OL2000.08)

Type locality: Kilinailau Trench, Station 63 $\left(02^{\circ} 23^{\prime} 99^{\prime \prime} \mathrm{N} 152^{\circ} 50^{\prime} 83^{\prime \prime} \mathrm{E}\right) \quad 1,813 \mathrm{~m}$ depth, 28 July 1998, subsample of GKG archive no. 17581-1.

Type habitat: grey and brown medium sand covered by a 2-cm-thick layer of fresh volcanic ash with Foraminifera shells and tiny basaltic pepperites with a very low percentage of fine organic material.

\section{Etymology}

The species name refers to the slim and simple (lat. simplex) toes (lat. digitus) of the larva, which lack any mucros.

\section{Measurements}

Table 1 
Table 1 Morphometric data of Phoeniciloricus simplidigitatus gen. et sp. nov.; measurements in brackets are likely to be different in the fully extended specimen. See text for explanation of abbreviations

\begin{tabular}{|c|c|c|c|}
\hline & Postlarva & & Higgins-larva \\
\hline \multicolumn{2}{|l|}{ Length of: } & \multicolumn{2}{|l|}{ Length of: } \\
\hline mouth cone & $15 \mu \mathrm{m}$ & body & $168 \mu \mathrm{m}$ \\
\hline mouth tube & $40 \mu \mathrm{m}$ & introvert & $20 \mu \mathrm{m}$ \\
\hline oral stylet & $5 \mu \mathrm{m}$ & thorax & $68 \mu \mathrm{m}$ \\
\hline oral ridge & $7 \mu \mathrm{m}$ & lorica & $76 \mu \mathrm{m}$ \\
\hline external furca & $9 \mu \mathrm{m}$ & & \\
\hline introvert & (25) $\mu \mathrm{m}$ & $\mathrm{cr}_{1}$ & $40-45 \mu \mathrm{m}$ \\
\hline thorax & (30) $\mu \mathrm{m}$ & $\mathrm{sr}_{2}$ & $30-35 \mu \mathrm{m}$ \\
\hline lorica & $135 \mu \mathrm{m}$ & $\mathrm{sr}_{3}$ & $28-42 \mu \mathrm{m}$ \\
\hline anal cone & $12 \mu \mathrm{m}$ & $\mathrm{sr}_{4}$ & $13-35 \mu \mathrm{m}$ \\
\hline midventral lo plate & $115 \times 48 \mu \mathrm{m}$ & $\mathrm{Sr}_{5}$ & $14-28 \mu \mathrm{m}$ \\
\hline middorsal lo plate & $130 \times 46 \mu \mathrm{m}$ & $\mathrm{sr}_{6}$ & $14-19 \mu \mathrm{m}$ \\
\hline ventral spike & $4 \mu \mathrm{m}$ & $\mathrm{sr}_{7}$ & $3-7.5 \mu \mathrm{m}$ \\
\hline dorsal spike & $5 \mu \mathrm{m}$ & & \\
\hline lateral spike & $7 \mu \mathrm{m}$ & $\mathrm{la}_{1}$ & $32 \mu \mathrm{m}$ \\
\hline $\mathrm{cr}_{1}$ & $68 \mu \mathrm{m}$ & $\mathrm{la}_{2}$ & $15 \mu \mathrm{m}$ \\
\hline $\mathrm{Sr}_{2} \mathrm{a} / \mathrm{sr}_{2} \mathrm{~b}$ & $42 / 70 \mu \mathrm{m}$ & $\mathrm{la}_{3}$ & $8 \mu \mathrm{m}$ \\
\hline $\mathrm{sr}_{3} \mathrm{a} / \mathrm{sr}_{3} \mathrm{~b}$ & $70 / 76 \mu \mathrm{m}$ & & \\
\hline $\mathrm{sr}_{4}$ & $55 \mu \mathrm{m}$ & toes & $72 \mu \mathrm{m}$ \\
\hline $\mathrm{sr}_{5}$ & $50 \mu \mathrm{m}$ & spine tip & $60 \mu \mathrm{m}$ \\
\hline $\mathrm{sr}_{6}$ & - & bases & $12 \mu \mathrm{m}$ \\
\hline $\mathrm{sr}_{7}$ & $53 \mu \mathrm{m}$ & & \\
\hline $\mathrm{sr}_{8}$ & $5 \mu \mathrm{m}$ & $\mathrm{se}_{1}$ & $37 \mu \mathrm{m}$ \\
\hline $\operatorname{tr}_{1}$ & $22 \mu \mathrm{m}$ & $\mathrm{se}_{2}$ & $25 \mu \mathrm{m}$ \\
\hline $\operatorname{tr}_{2}$ & $30 \mu \mathrm{m}$ & $\mathrm{se}_{3}$ & $3 \mu \mathrm{m}$ \\
\hline Diameter of: & & Diameter of: & \\
\hline lorica & $80 \mu \mathrm{m}$ & lorica & $87 \mu \mathrm{m}$ \\
\hline pharynx bulb & $28 \mu \mathrm{m}$ & & \\
\hline
\end{tabular}

\section{Description of Higgins-larva}

Figs. 2, 3 and 7A-D

The last instar Higgins-larva is a well-preserved exuvium which does not contain any tissue, but has a fully developed postlarva. The larval body is divided into introvert, thorax and lorica. Each of these body regions is a tagma, or functional unit, as known from the Arthropoda or Annelida. The exuvium represents a larva with a stubby body, a thorax divided by many cuticular plates, a rounded lorica and spinose toes lacking mucros. Additional distinguishing features are numerous flosculi in the collar region as well as in the posteriormost part of the lorica, and three pairs of bristle-like locomotory appendages. No mouth cone or other mouth parts can be observed in this specimen. The body of the Higgins-larva (Figs. 2, 3) is $168 \mu \mathrm{m}$ long. The widest part in the middle of the lorica is $87 \mu \mathrm{m}$. In the mounted specimen, all body regions, except for the absent mouth cone, are extended. The enclosed postlarva totally fills the larval exuvium and makes the larval lorica rounder than a living specimen would be. The Higgins-larva shows a more distinct bilateral symmetry than the postlarva.

The spherical introvert (Fig. 7B) is densely covered with seven circles of scalids. The scalids on the ventral and dorsal sides differ in length and modification, making the bilateral symmetry of the larval body apparent. The

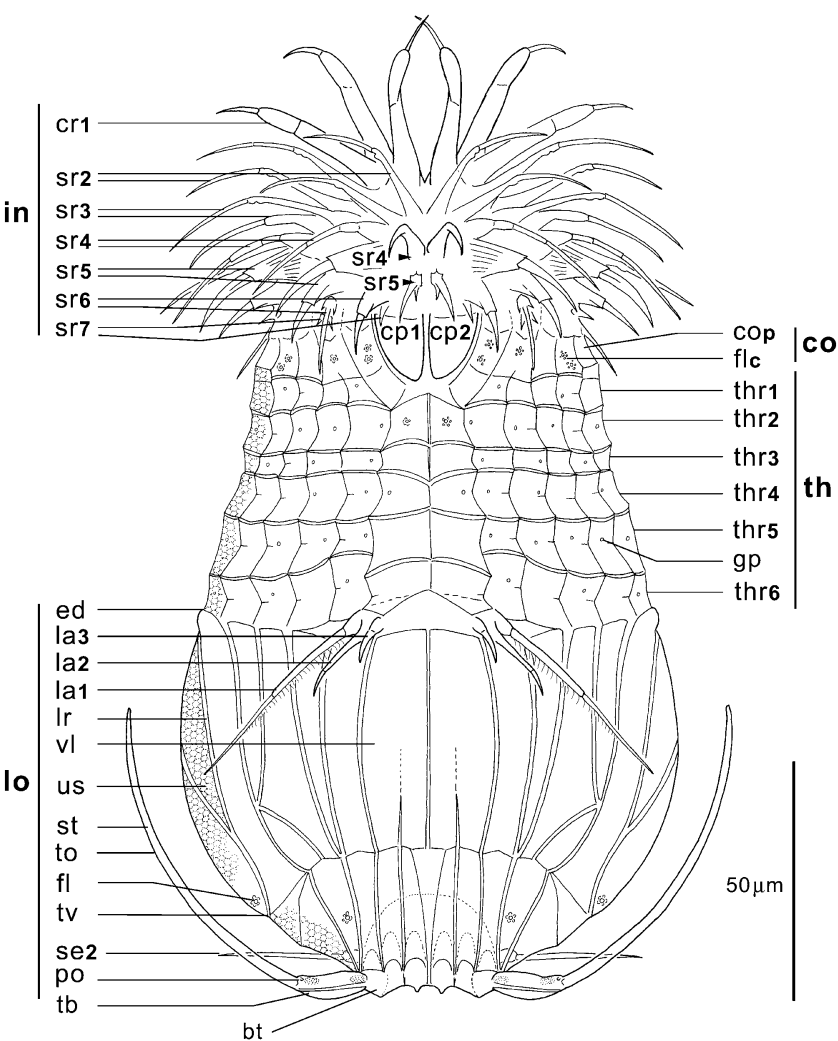

Fig. 2 Phoeniciloricus simplidigitatus gen. et sp. nov., Higginslarva, ventral view. $b t$ Basal plate of toe; $c o$ collar region; $c o p$ collar plate; $c p_{1-2}$ closing plate of larva; $c r_{1}$ clavoscalid of first row; $e d$ edge or rim of lorica; $f l$ papillate flosculi; $f l c$ flosculi of larval collar; $g p$ pore of subcuticular gland; in introvert; $l a_{1}$ anterolateral appedage; $l a_{2}$ anteromedial appendage; $l a_{3}$ anteroventral appendage; lo lorica; $l r$ ridge of larval lorica; po pore; $s e_{2}$ posterolateral sensory seta; ${s r_{2-7}}_{2}$ second to seventh row of spinoscalids; $s t$ spinetip of toe; $t b$ base of toe; th thorax; $t h r_{1-6}$ first to sixth rows of thoracic plates; to toe; $t v$ transversal constriction; $u s$ ultrasculpture; $v l$ ventral lorica

scalids in the posterior half of the introvert are not in line with the strict circular arrangement known from the postlarva. Instead, they are arranged in a zigzag pattern forming subcircles. Eight slightly spinose clavoscalids $\left(\mathrm{cr}_{1}\right)$ form the first row of scalids. All of them are divided into three segments and are of the same length, despite the slightly smaller midventral pair. The distal segment is an elongated spine.

The remaining six circles of scalids bear spinoscalids. It is difficult to make out the midventral scalid arrangement. Here, the scalids leave the strict row-like arrangement and are slightly modified. The second and third rows bear typical elongate spinoscalids which stand so close together that separate rows are difficult to discriminate.

However, the second row $\left(\mathrm{sr}_{2}\right)$ contains the full set of ten spinoscalids. Each first segment of these spinoscalids is composed of a swollen base, followed by a long narrow stalk. A well-developed hinge joint connects the stalk with a long, spinose, distal segment. 


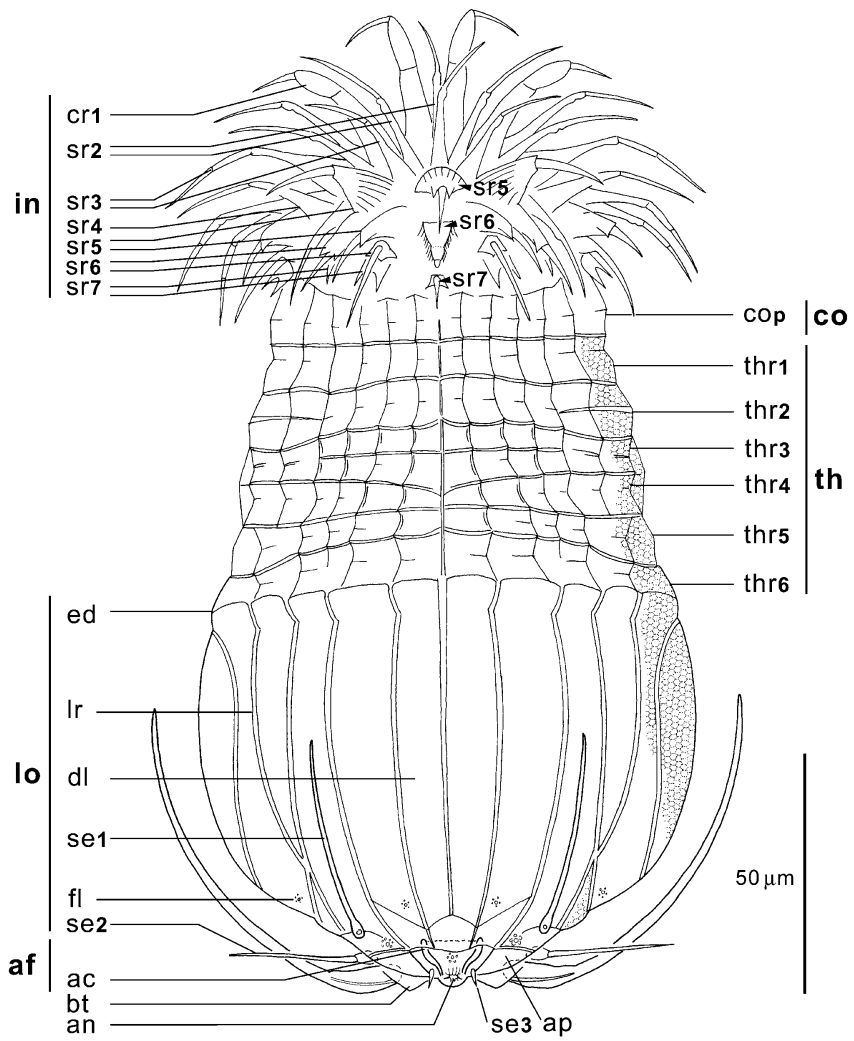

Fig. 3 Phoeniciloricus simplidigitatus gen. et sp. nov., Higginslarva, dorsal view. ac Anal cone; af anal field; an anus; ap anal plate; $b t$ basal plate of toe; $c o$ collar region; $c o p$ collar plate; $c r_{1}$ clavoscalid of first row; $d l$ dorsal lorica; $e d$ edge or rim of lorica; $f l$ papillate flosculi; in introvert; $l o$ lorica; $l r$ ridge of larval lorica; $s e_{1}$ posterodorsal sensory seta; $s e_{2}$ posterolateral sensory seta; $s e_{3}$ posteroterminal sensory seta; $\mathrm{Sr}_{2-7}$ second to seventh row of spinoscalids; th thorax; $t h r_{1-6}$ first to sixth rows of thoracic plates

The remaining rows of scalids contain a maximum of 15 spinoscalids like the third row $\left(\mathrm{sr}_{3}\right)$. All scalids of the third and fourth rows have the same structure as those of the second row. Starting at the ventral midline, each pair in the fourth row $\left(\mathrm{sr}_{4}\right)$ is slightly modified and the spinoscalids in this row are displaced into upper and lower subcircles. The midventral pair of scalids is transformed into massive hooks.

The fifth row $\left(\mathrm{sr}_{5}\right)$ is divided into two subcircles, the upper subcircle consisting of seven large spinoscalids divided into two segments. The first segment is conical, with a wide base and lateral longitudinal stripes. The spinose second segment is bent like a claw. These seven large upper spinoscalids alternate with eight smaller spinoscalids which form the lower subcircle. These spinoscalids have conical basal segments, each flanked by a pair of small subdorsal thorns and ending in a spinous distal segment. The midventral pair of scalids in the lower subcircle appears as simple hooks.

The seven spinoscalids forming the upper subcircle of the sixth row $\left(\mathrm{sr}_{6}\right)$ have the same structure. They alternate with six moderately long, filiform lower subcircle scalids which arise from basal plates. The dorsal filiform scalids are longer than the ventral ones. The midventral pair of the lower subcircle is reduced to small spines and located immediately under the midventral pair of spinoscalids of the previous, fifth row. A single spinoscalid of the sixth row in the middorsal position is modified (a sensor?) like in the Higgins-larva of N. mysticus (Kristensen 1991b) and covered with fine, hairy spinules.

The last and seventh row $\left(\mathrm{sr}_{7}\right)$ of scalids consists of eight single spinose projections alternating with seven double spinose projections. In the midventral sector, all spinoscalids of the fifth to seventh rows are distinctly modified (hook-like).

The thorax (th) is a flexible, accordion-like tagma. Its thin cuticle is divided into transverse rows of thoracic plates $\left(\operatorname{thr}_{1-6}\right)$. All plates can be transversally folded once. Ventrally, the thorax bears six rows of plates, those on both sides of the midventral line being slightly enlarged. The dorsal thoracic plates are generally smaller and also form six rows, but the third row is subdivided into two secondary rows. A similar row of plates (cop) marks the transition between introvert and thorax as a weakly defined neck. Two midventral plates $\left(\mathrm{cp}_{1}, \mathrm{cp}_{2}\right)$ of this row are visibly enlarged and sclerotized, forming a closing apparatus when the introvert is withdrawn. This additional row of cuticular plates, together with the pair of large midventral closing plates, represents the collar region (co) as found in Higgins-larvae of the Pliciloricidae. There are numerous small papillate flosculi (flc), especially on the ventral neck plates. The development of large closing plates has the effect that the strongly modified midventral scalids are pushed frontally and are concentrated in a smaller sector.

Ventrally, three pairs of appendages (assumed to have a locomotory or grasping function) are situated on a transition belt between thorax and lorica. The outer pair of these appendages $\left(\mathrm{la}_{1}\right.$; Figs. $\left.7 \mathrm{C}, 8 \mathrm{E}\right)$ is slightly segmented, long, setiform and covered with fine setules, so fine that they are hardly visible under a light microscope. The two inner pairs of appendages $\left(\mathrm{la}_{2}, \mathrm{la}_{3}\right)$ are much shorter and resemble hooks. None of the three pairs of appendages are fused basally.

The rounded abdomen is covered with a slightly thicker cuticle forming a lorica (lo). The lorica is divided by 18 deep longitudinal primary folds (lr) into fields of different sizes. Eight of these primary folds are branched, each forming two secondary folds. The surface of the lorica shows a weakly developed honeycomb ultrasculpture which is less distinct on other parts of the trunk. Ventrally, the lorica is divided posteriorly into two portions by a transverse constriction. The constriction makes the ventral side become flat, while the dorsal side is bulged. There are four small papillate flosculi on both the dorsal and ventral sides in the posteriormost region of the lorica.

The toes (to), a pair of modestly long appendages, extend ventrally from the caudal end of the trunk (Figs. 7D, 8E) and articulate via ball-and-socket joints on modestly developed basal plates (bt). These conspicuous features of all Higgins-larvae are distally drawn out 


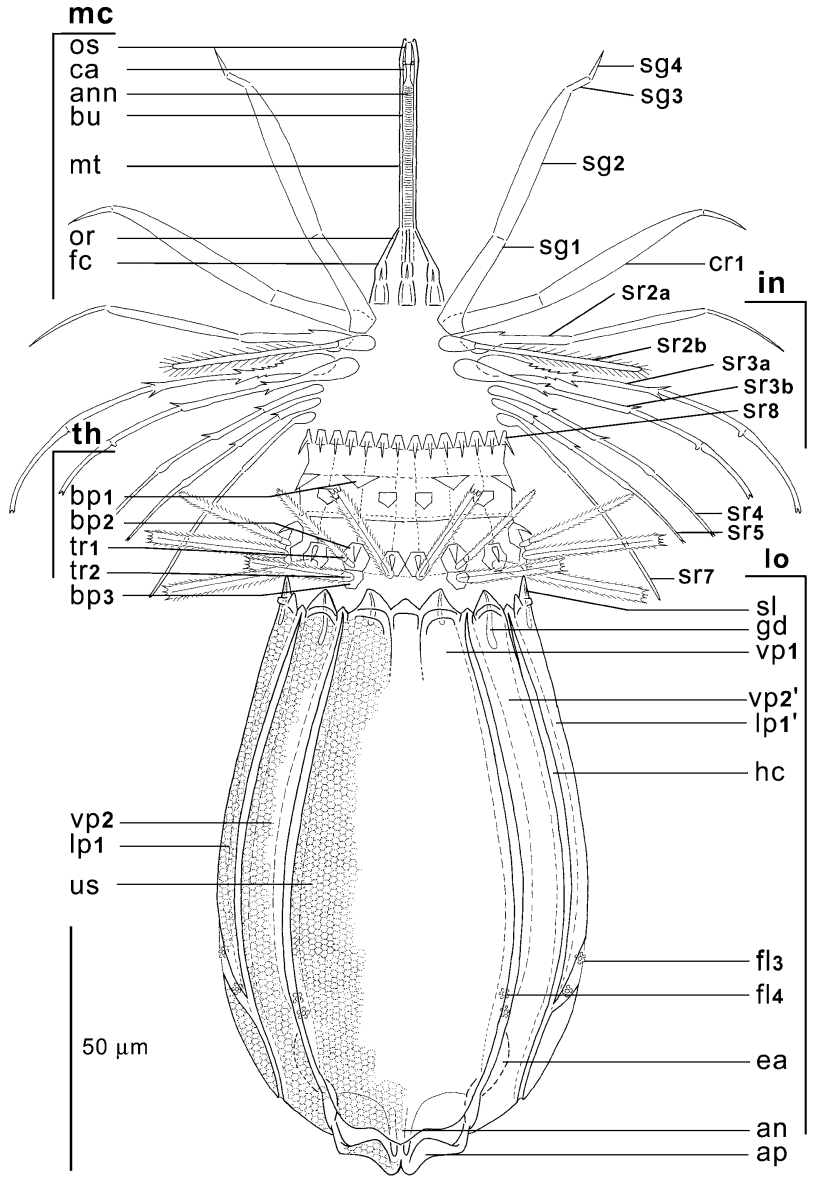

Fig. 4 Phoeniciloricus simplidigitatus gen. et sp. nov., postlarva, ventral view, reconstruction of extended introvert from withdrawn introvert in Fig. 6. an Anus; ann annuli; ap anal plate; $b p_{1-3}$ basal plates of neck; $b u$ buccal tube; $c a$ oral closing apparatus; $c r_{1}$ clavoscalid of first row; $e a$ locking apparatus of lorica plates; $f c$ external furca of mouth cone; $f l_{3}$ midventral pair of flosculi; $f l_{4}$ ventrolateral flosculi on hinge cuticle; $g d$ gland duct; $h c$ hinge cuticle; in introvert; lo lorica; $l p_{1}$ right dorsolateral plate of lorica; $l p_{l}^{\prime}$ left ventrolateral plate of lorica; $m c$ mouth cone; $m t$ mouth tube; or anterior oral ridge; os oral stylet; $s g_{1-4}$ first to fourth segment of scalid; $s l$ spike of lorica; $s r_{2-8}$ second to eighth row of spinoscalids; $s r_{2} a$ type A scalids of second row; $s r_{2} b$ type B scalids of second row; $s r_{3} a$ type A scalids of third row; $s r_{3} b$ type B scalids of third row; th thorax; $t r_{1}$ trichoscalid of upper circle; $t r_{2}$ trichoscalid of lower circle; $u s$ ultrasculpture; $v p_{1}$ midventral plate of lorica; $v p_{2}$ right inner ventrolateral plate of lorica; $v p_{2}{ }^{\prime}$ left inner ventrolateral plate of lorica

in a rigid and hollow spine-tip (st), which makes up more than $80 \%$ of the total toe length. The bases of the toes are only slightly developed in this specimen. A lateral enlargement, such as a mucro, is missing. Instead, a slightly elevated bar is present on both lateral surfaces of the small toe bases. A single pore can be observed to perforate the distal inner part of the toe bases. Other appendages of the lorica include three pairs of caudal sensory setae. A pair of reduced posteroterminal setae $\left(\mathrm{se}_{3}\right)$ is located on the anal field and a pair of posterodorsal setae $\left(\mathrm{se}_{1}\right)$ on the posterior end of the lorica. Laterodorsally there is a third pair of posterolateral

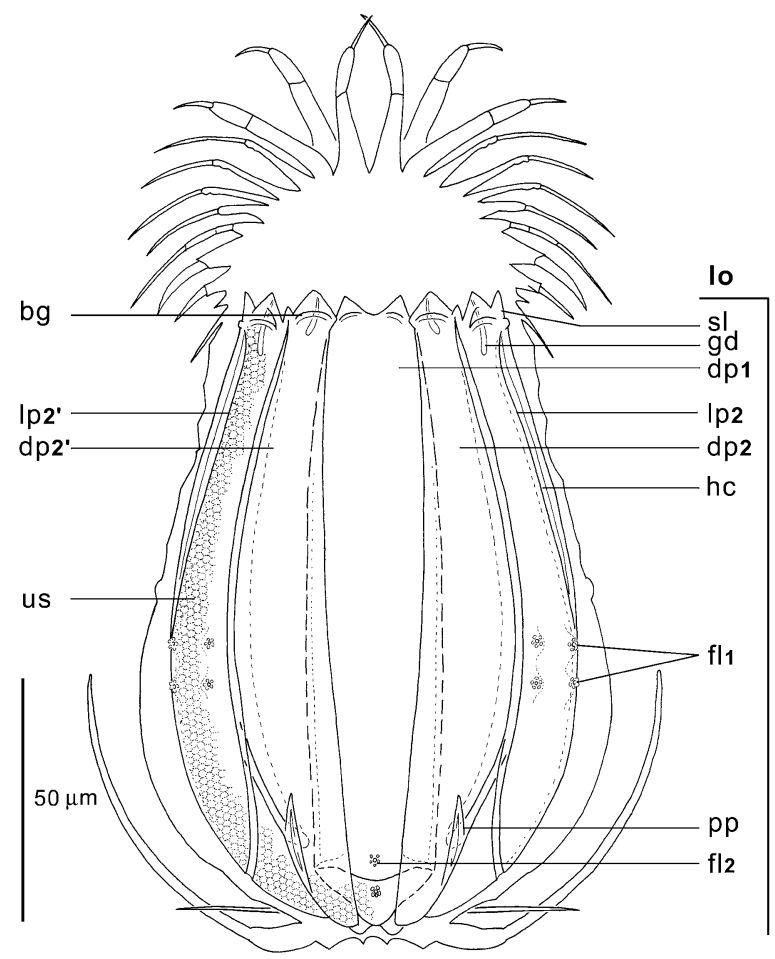

Fig. 5 Phoeniciloricus simplidigitatus gen. et sp. nov., postlarva, dorsal view, in original position in larval exuvium. $b g$ Transverse reinforcement (bridge); $d p_{1}$ middorsal plate of lorica; $d p_{2}$ right inner dorsolateral plate of lorica; $d p_{2}{ }^{\prime}$ left inner dorsolateral plate of lorica; $f l_{1}$ flosculi of middorsal plate; $f l_{2}$ dorso-lateral cluster of flosculi; $g d$ gland duct; $h c$ hinge cuticle; lo lorica; $l p_{2}$ right ventrolateral plate of lorica; $l p_{2}^{\prime}$ left dorsolateral plate of lorica; $p p$ posterior protrusion; $s l$ spike of lorica; $u s$ ultrasculpture

setae $\left(\mathrm{se}_{2}\right)$ with separate, jointed bases. The pairs of posterodorsal and posterolateral setae differ in length. The anal cone (ac) is situated dorsally and is surrounded by anal plates (ap) which form the anal field (af). The central anal plate is defined by margins folding upwards and bearing a single, large papillate flosculum in the middle. The anus (an) lies posteriorly to this plate. A pair of additional, but smaller, papillate flosculi can be found nearby on both sides of the central anal plate.

\section{Description of postlarva}

Figs. 4, 5, 6 and 7E-H

The postlarva is of medium size and has a rounded, urn-shaped lorica. Mouth cone, introvert and thorax are totally withdrawn into the lorica. That is the reason why the lorica and associated structures will be described first. The small size of loriciferans and the transparent cuticle enable all features, even the retracted parts of the body, to be distinguished. For a better overview, the withdrawn body region is represented in Fig. 4 as though it were totally extended.

The rounded abdomen (lo) is armoured with massive lorica plates (Figs. 4,5). The lorica measures $137 \mu \mathrm{m}$ in 


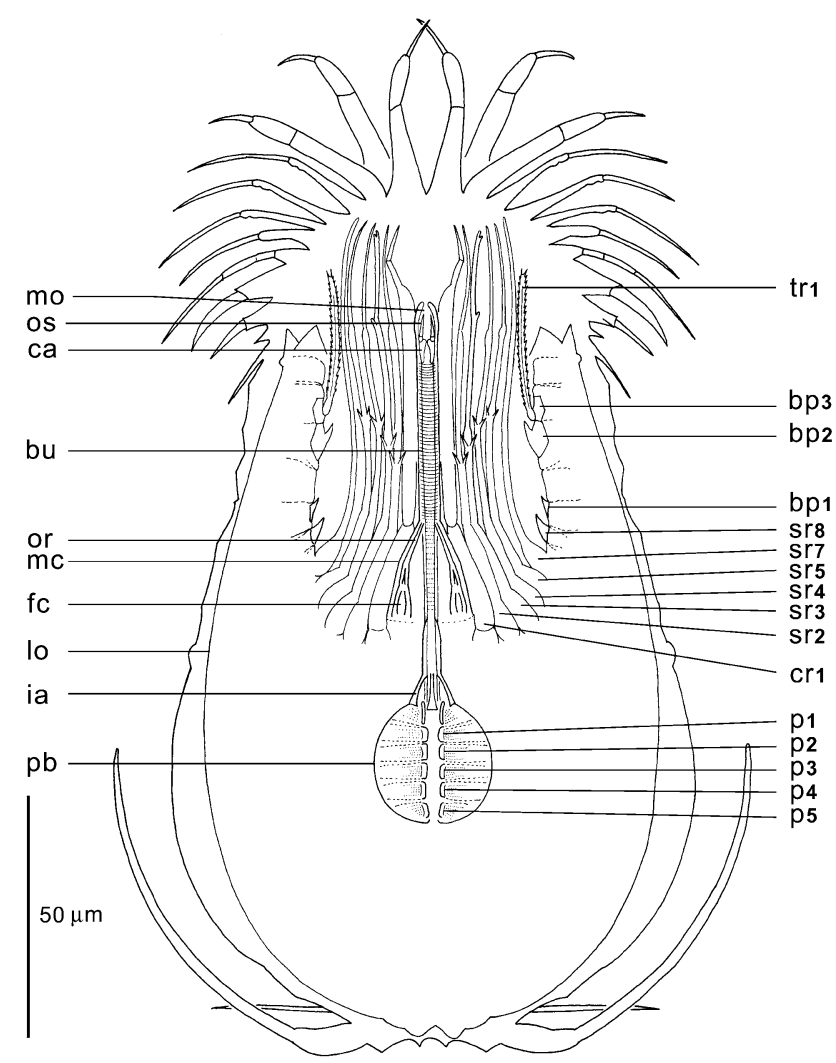

Fig. 6 Phoeniciloricus simplidigitatus gen. et sp. nov., postlarva, in original position in the larval exuvium with retracted introvert and internal details. $b p_{1-3}$ Basal plates of neck; $b u$ buccal tube; $c a$ oral closing apparatus; $c r_{1}$ clavoscalid of first row; $f c$ external furca of mouth cone; ia prepharyngeal armature; lo lorica; $m c$ mouth cone; mo mouth opening; or anterior oral ridge; os oral stylet; $p_{1-5}$ first to fifth row of placoids; $p b$ pharynx bulb; $s r_{2-8}$ second to eighth row of spinoscalids; $\operatorname{tr}_{1}$ trichoscalid of upper circle

length and $85 \mu \mathrm{m}$ in maximal width. The surface of its cuticle has a distinct honeycomb ultrasculpture (us; Fig. 7G). The lorica is divided into ten longitudinal plates (Fig. 9, c.1) connected laterally by cuticular hinges (hc). The midventral $\left(\mathrm{vp}_{1}\right)$ plate is broad, while the middorsal plates $\left(\mathrm{dp}_{1}\right)$ and eight lateral plates are narrow. To allow sliding movements, the midventral $\left(\mathrm{vp}_{1}\right)$ and both adjacent inner ventrolateral plates $\left(\mathrm{vp}_{2}, \mathrm{vp}_{2}{ }^{\prime}\right)$ are laterocaudally connected by a locking apparatus (ea) with ridges and opposing sockets. The anterior rim of the lorica is armed with 13 small spikes (sl; Fig. 7F): three on the midventral plate, two on the middorsal plate, and one on each of the eight narrow remaining plates. All spikes are transversally reinforced at their bases by thick cuticular walls, called bridges, of lorica spikes (bg). Internally, each spike has subcuticular glands with small lacunas and ducts running anteriorly (gd). The lorica plates are perforated by several small pores (not drawn because hardly visible) communicating with the subcuticular glands. The outer lateral margins of the middorsal plate (dp1) are folded up and together, with the inner lateral margin of both inner dorsolateral plates $\left(\mathrm{dp}_{2}, \mathrm{dp}_{2}{ }^{\prime}\right)$ covering the remaining portion of the middorsal plate. Two clusters of four papillate flosculi (fl) are located dorsally on the left and right sides in the posterior half of the lorica. They are located on small cuticular elevations. The middorsal plate has a rounded end and two flosculi caudally. The anus (an) opens ventrally at the caudal end and is covered dorsally by a double anal plate (ap) which overlaps the anus like a shield from behind. Two laterodorsal cuticular formations, resembling lanceolate protrusions ( $\mathrm{pp}$ ), flank the caudal end.

The mouth cone can be withdrawn inside the lorica, but not inside the introvert (as in all Nanaloricidae). The mouth cone $(\mathrm{mc})$ is clearly separated from the introvert and consists of two sections. The broad basal section is surrounded by eight identical, heavily sclerotized and elevated supporting structures. These structures are subdivided into the oral ridges (or) and the oral furcae (fc). The oral ridges are short and the furcae are located in the midsections of the oral ridges. The furcae are the point of attachment for the eight retractor muscles of the mouth cone. The terminal section of the mouth cone is the narrow mouth tube (mt; Fig. 7H). It is more than twice as long as the basal section. The mouth opening (mo) is situated terminally on the tip of the mouth tube. Six minute oral stylets (os) surround the inside of the mouth opening. They articulate internally with the mouth tube wall above the closing apparatus (ca) of the buccal tube. The internal buccal channel is sclerotized to form a buccal tube (bu) $(78 \mu \mathrm{m})$ which is twice as long as the mouth tube (Fig. 6). It can be partly extended telescopically out of the mouth opening. On the inner cuticular layer of the buccal tube, a fine, characteristic striation or annuli (ann) can be found, which makes it more flexible. Internally, the buccal tube traverses the mouth cone and the brain and extends into the large, round pharynx bulb. Posteriorly, the buccal tube is united with a complex prepharyngeal armature (ia). The internal armature consists of bracelets in a triradiate arrangement and is anchored to the round pharyngeal bulb by a short manubrium. The muscular pharynx bulb (pb) is located deep inside the trunk. The pharyngeal lumen is paved with five rows of cuticular placoids $\left(\mathrm{p}_{1-5}\right)$. The placoids seems to be connected to one another longitudinally in a chain-like manner.

Fig. 7A-H Phoeniciloricus simplidigitatus gen. et sp. nov. (interference-contrast photographs). A habitus of the Higgins-larva; B details of larval introvert; $\mathbf{C}$ anterior edge of larval lorica with appendages; $\mathbf{D}$ caudal end of the Higgins-larva with toe and sensory seta; $\mathbf{E}$ habitus of enclosed postlarva; $\mathbf{F}$ anterior edge of postlarval lorica with spikes; $\mathbf{G}$ ultrasculpture of postlarval lorica; $\mathbf{H}$ view on retracted scalids and tip of mouth tube. $b g$ Transverse reinforcement (bridge); $b u$ buccal tube; $c r_{1}$ clavoscalid of first row; $e d$ edge or rim of lorica; in introvert; $l a_{1}$ anterolateral appendage; Lar Higgins-larva; lo lorica; $l r$ ridge of larval lorica; $m t$ mouth tube; Pla postlarva; $s e_{2}$ posterolateral sensory seta; $s l$ spike of lorica; $s r_{2-4}, 6$ second to fourth, sixth row of spinoscalids; ss spinoscalid; $s s^{\prime}$ spinoscalid(s) of Higgins-larva; $s s^{\prime \prime}$ spinoscalid(s) of postlarva; $s t$ spine-tip of toe; $t b$ base of toe; to toe; $t v$ transverse constriction; $u s$ ultrasculpture 

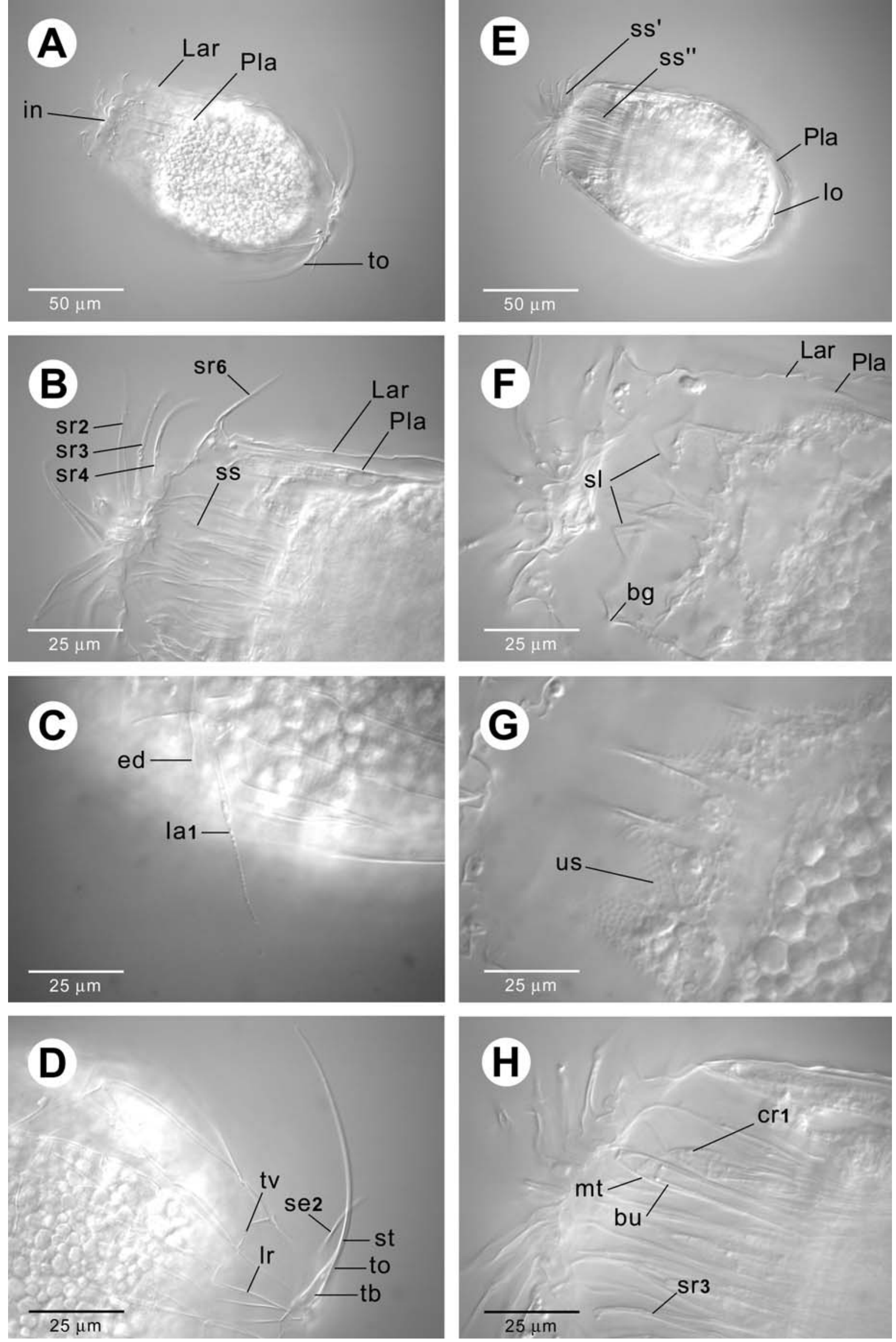
The introvert (in) is densely covered with eight rows, or circles, of scalids. The first row $\left(\mathrm{cr}_{1}\right)$ consists of eight identical, non-branched clavoscalids. All of them are inserted into the introvert with triangular bases forming joints. The clavoscalids are divided into four segments. The first segment is a long stalk and forms a unit with the bases. The second segment is the longest, and laterally flattened. The last two segments are small. The most distal segment ends in a spine-tip which is oriented upwards.

The next seven rows of scalids consist of spinoscalids. Most of these spinoscalids possess bulbous bases. The second row $\left(\mathrm{sr}_{2}\right)$ of scalids consists of 16 spinoscalids of two different types. Nine scalids represent type A scalids $\left(\mathrm{sr}_{2} \mathrm{a}\right)$. They are strongly sclerotized and are the same length as the clavoscalids. Each of them is segmented like a leg and consists of four segments. The fourth segment is laterally flattened and slightly enlarged, but narrower than the clavoscalids. The terminal segments are spinose. The nine type A spinoscalids regularly alternate with seven smaller ones representing type B scalids $\left(\mathrm{sr}_{2} \mathrm{~b}\right)$. Type B spinoscalids are short and have only two segments. The second segment is filiform and covered over the entire length with numerous fine hairy spinules, giving them a feather-like appearance.

The third row $\left(\mathrm{sr}_{3}\right)$ of scalids also consists of 16 spinoscalids of two slightly different types. Both spinoscalid types have four segments. Their basal segment is spiny, and the well-developed hinge joints between the segments bear two lateral spikes. The eight type A spinoscalids $\left(\mathrm{Sr}_{3} \mathrm{a}\right)$ are slightly bigger and longer, and have more pronounced spikes than the type B spinoscalids. In both spinoscalid types, the third segment ends with a subventral tooth and the terminal segment ends in a double claw-tip. Type B scalids $\left(\mathrm{sr}_{3} \mathrm{~b}\right)$ are homologous with claw-shaped scalids of other loriciferans.

The following rows have a maximum number of 30 spinoscalids each. The fourth $\left(\mathrm{sr}_{4}\right)$ and fifth $\left(\mathrm{sr}_{5}\right)$ rows each possess a circle of spinoscalids which are filiform and more flexible than the scalids described previously. They consist of four segments. Their short bases and all other segments have hinge joints. The terminal segment is elongated and ends in a double tip. The sixth row is missing (as in all described postlarvae of Nanaloricidae).

In the seventh row $\left(\mathrm{sr}_{7}\right)$, the scalids are more flattened and flexible, and are not divided into segments. They are inserted on small basal plates. The eighth $\left(\mathrm{sr}_{8}\right)$ and last row consists of small teeth-like scalids, which are inserted on trapeziform plates.

The intermediate body region, the thorax (th), begins directly behind the eighth row of scalids. It carries three rows of basal plates and an additional 22 trichoscalids, seven double and eight single. The basal plates of the first row $\left(\mathrm{bp}_{1}\right)$ are smooth and elevated. Seven basal plates have a triangular shape and eight are more angular. Between the first and second rows of basal plates, there is a flexible zone consisting of pure cuticle. The following part of the thorax is covered by the second and third rows of basal plates. Basal plates of the second row $\left(\mathrm{bp}_{2}\right)$ are large and shield-like, each with a small erect tooth and a trichoscalid. Eight larger trichoscalids insert directly in the basal plates and end in four finely pointed tips. These eight trichoscalids alternate with seven smaller and thinner ones which have smooth shafts and simple pointed tips. The basal plates of the third row $\left(\mathrm{bp}_{3}\right)$ are smaller and every second one carries a large lower trichoscalid $\left(\operatorname{tr}_{2}\right)$. These trichoscalids are associated with seven small upper trichoscalids $\left(\operatorname{tr}_{1}\right)$. All trichoscalids have a similar structure. They are filiform, rigid and slightly flexible, with finely serrated lateral margins. In cross-section, all large trichoscalids are flat with a central canal and four-pointed tips. Additionally, a third protruding margin is present perpendicular to the central canal, with the same kind of serration as the lateral margins. The small trichoscalids seem to have a simpler structure, no central canal or protruding margins are visible, and the tips have single points. Midventrally there are two large, single trichoscalids on both sides of the ventral central axis. A double trichoscalid is located middorsally on the dorsal central axis.

\section{Discussion}

\section{General remarks}

Kristensen (1991a) discovered a postlarval stage in the life cycle of Nanaloricus mysticus Kristensen, 1983. Postlarval stages of Nanaloricidae are found very rarely. Only one specimen of $N$. mysticus is known so far which shows all features found in adult females: the scalids of the introvert, the mouth cone and the lorica consisting of plates. The postlarva differs slightly from the adults in the following ways:

1. It reaches only $80 \%$ of the size of the adults, with mouth cone, lorica spikes and scalids being slightly shorter in relation to total body size;

2. The body cavity is filled with granular storage cells and the sexual reproductive organs are not developed;

3 . The sixth row of spinoscalids is missing or developed as protoscalids (Kristensen and Gad 2003).

Sexual dimorphism, as expressed in the branched clavoscalids of males, is not recognisable. It is generally impossible to predict which sex will emerge from a postlarva. The sex is visible for the first time when the developing adult takes shape inside the postlarval exuvium. The study of four postlarvae, representing four different species, indicates that a postlarva of the Nanaloricidae type generally has the same morphology as the respective mature females of the four species, except for the missing sixth row of spinoscalids and the small differences listed above (Gad 2003; Kristensen and Gad 2003). Larger differences in morphology between postlarvae and adults, which are common in Pliciloricidae according to Kristensen and Brooke (2002) and Gad 
(2003), are not to be expected. Therefore, the features of the Nanaloricidae postlarva can be used in the following discussion to infer features of unknown adults.

Comparative diagnosis

\section{Higgins-larva}

The present results are compared here with species of Nanaloricidae, other than the already-described N. mysticus, which are the object of forthcoming publications (Gad 2003; Kristensen and Gad 2003). The most conspicuous feature of the Higgins-larva of $P$. simplidigitatus sp. nov. is the structure of the toes, which generally differs between the larvae of different species and is a good distinguishing character (Fig. 8). In species of Nanaloricidae, the toes are basally enlarged and continue into a long spine. In the genus Nanaloricus, the toes are flattened and laterally equipped with a series of leaf-like structures, called mucros (Fig. 8A). A similar structure with slightly different mucros has been found in two new, rather similar species representing a new genus discovered at Trezen ar Skoden (Roscoff, France) inhabiting shell gravel at 50-55 m depth (Kristensen and Gad 2003). The Higgins-larva of species I, representing the new genus Armorloricus, is shown in Fig. 8B for comparison. This larva has a short mucro ending in two diverging tips. Two new species, belonging to two new genera of Nanaloricidae, have been reported recently from the Great Meteor Seamount, where they also inhabit shell gravel covering the plateau ( $\mathrm{Gad} 2003)$. The toes of one of these new species, representing a new genus and called species II here, lack mucros, but the cuticle of the broad base of the toes has a regular pattern of elevated cuticular ridges like the diverging net-veins of dicotyledonous leaves (Fig. $8 \mathrm{E})$. The toes of the other new species, representing another new genus and called species III here, have simple, but conspicuously enlarged bases without mucros or cuticular ridges (Fig. 8C). The toes of the Higgins-larva of $P$. simplidigitatus are more similar to those of the larva of species III from the Great Meteor Seamount, but they are shorter in relation to the total body length and their bases are much less enlarged (Fig. 8D). Compared with all other known larvae of Nanaloricidae, $P$. simplidigitatus has the simplest toes. Apart from the toes, the distinguishing features which separate the larva of $P$. simplidigitatus from all other mentioned nanaloricid larvae are:

1. The scalids of the introvert are clearly shorter

2. The thorax is made up of 6-8 rows of thoracic plates, some of them arranged in subrows

3. Numerous small papillate flosculi are located in the anterior region of the thorax and at the caudal end

4. Anterior appendages are more filiform and less hooklike, and

5. The transformation of scalids into hooks in a midventral sector of the introvert is less obvious.

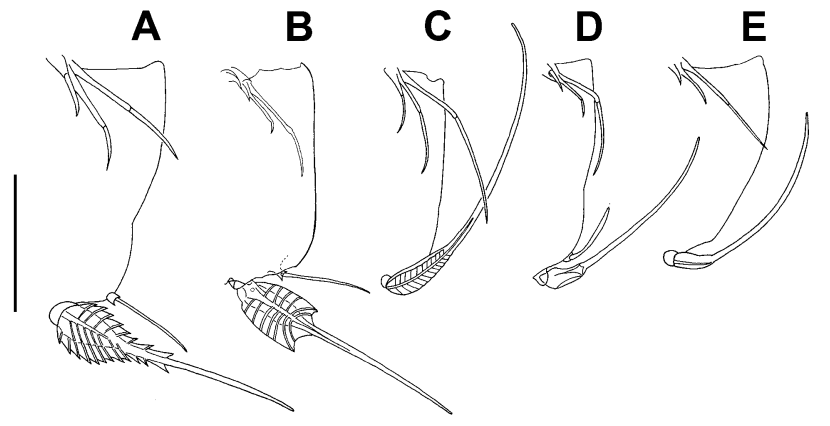

Fig. 8A-E Structure of toes and anterior appendages in different Higgins-larvae representing various genera of Nanaloricidae. A Nanaloricus mysticus; B Armorloricus sp. I; C gen. et sp. nov. II from the Great Meteor Seamount; D gen. et sp. nov. III from the Great Meteor Seamount; E P. simplidigitatus gen. et sp. nov.; bar $50 \mu \mathrm{m}$

The postlarva of $P$. simplidigitatus fits perfectly into the characterisation of the Nanaloricidae:

1. The long mouth cone is not retractable into the introvert

2. The mouth cone has six strong elevated external furcae and oral ridges

3. The large, round pharyngeal bulb has five rows of placoids, separated from the mouth cone and located deep inside the trunk

4. The buccal channel has a sclerotized, telescopically movable buccal tube with annulated inner cuticle layer

5. The introvert has eight rows of scalids, but only seven in the postlarval stage

6. The first row of basal plates is modified and separated from the second row by a broad thoracic region (=anterothorax)

7. trichoscalids are short, double trichoscalids separated basally

8. The lorica is armoured with strong plates, having hollow spikes at their anterior margin.

9. cluster of papillate flosculi concentrated in posterior half of lorica.

\section{Postlarva}

The structure of the lorica and the mouth cone generally differs between the postlarvae (and adults) of different species of Nanaloricidae (Fig. 9) and are good key characters for species separation. The postlarva of $P$. simplidigitatus shows an interesting mixture of features. It shares many characteristic features with Armorloricus sp. I (Fig. 9B) discovered in the vicinity of the type locality of $N$. mysticus near Roscoff, France (Kristensen and Gad 2003):

1. Mouth cone short, bearing eight elevated external furcae and oral ridges, and having an extremely long mouth tube (Fig. 9, b.5, c.5)

2. Tooth-like spinoscalids in the eighth row of scalids 


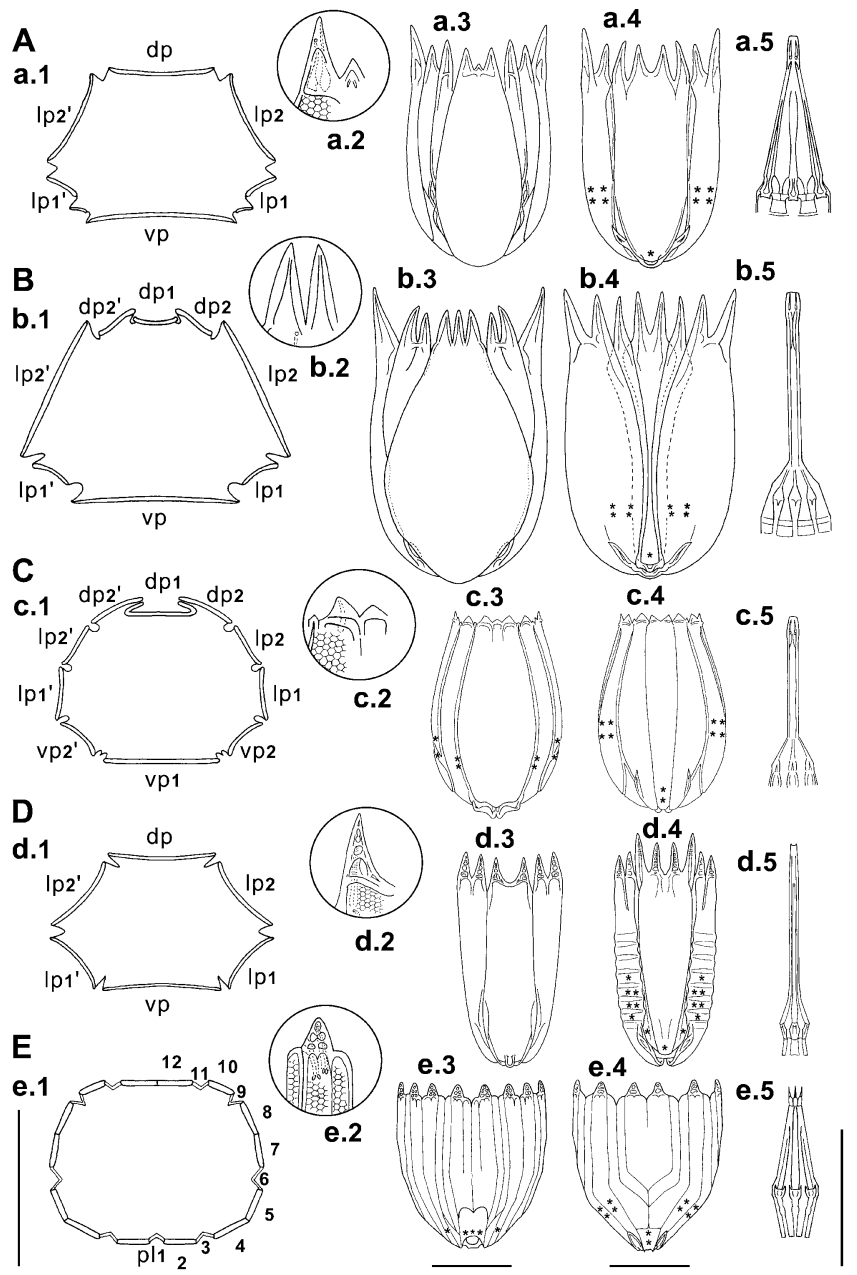

Fig. 9A-E Structure of lorica and mouth cone of different species representing various genera of Nanaloricidae. A N. mysticus (adult); B Armorloricus sp. I from Roscoff (adult); C Phoeniciloricus simplidigitatus gen. et sp. nov. (postlarva); D gen. et sp. nov. II from Great Meteor Seamount (adult); $\mathbf{E}$ gen. et sp. nov. III from Great Meteor Seamount (postlarva). a.1-e.1 cross-section in the middle of the lorica; a.2-e.2 detail of midventral lorica spikes; a.3-e.3 ventral lorica; a.4-e.4 dorsal lorica; a.5-e.5 mouth cone. $d p$ Dorsal plate of lorica; $d p_{l}$ middorsal plate of lorica; $d p_{2}$ right inner dorsolateral plate of lorica; $d p_{2}{ }^{\prime}$ left inner dorsolateral plate of lorica; $l p_{1}$ right dorsolateral plate of lorica; $l p_{1}{ }^{\prime}$ left ventrolateral plate of lorica; $l p_{2}$ right ventrolateral plate of lorica; $l p_{2}{ }^{\prime}$ left dorsolateral plate of lorica; $p l_{1-12}$ plica; $v p$ ventral plate of lorica; $v p_{1}$ midventral plate of lorica; $v p_{2}$ right inner ventrolateral plate of lorica; $v p_{2}{ }^{\prime}$ left inner ventrolateral plate of lorica; * position of papillate flosculi; bar $50 \mu \mathrm{m}$

3. Broad dorsal plate of the urn-shaped lorica subdivided longitudinally into three plates, the inner lateral margins of both ventrolateral plates folded upwards and partly covering the midventral plate (Fig. 9, b.1, c.1), and

4. Elements of laterocaudal articulation (ridges and sockets) of lorica located caudally.

In species I from Roscoff the cuticle of the eight lorica plates is smooth and shiny without any ultrasculpture. In
P. simplidigitatus the lorica is divided into ten, not eight plates (Fig. 9, c.1). The lorica spikes are small and the surface of the lorica has a pronounced honeycomb ultrasculpture as known from the Nanaloricus species demonstrated in Fig. 9, a.2 (Kristensen 1983, 1991b; Todaro and Kristensen 1998). With these Nanaloricus species, $P$. simplidigitatus also shares the two types of spinoscalids in the third row. They differ only slightly in length and their bases are spiny, but their terminal segments end in identical double tips. Species II (Fig. 9D) and species III (Fig. 9E) from the Great Meteor Seamount have a different structure of the lorica (Fig. 9, d.1, d.3, d.4, e.1, e.3, e.4) and a mouth cone that is hardly comparable with that of $P$. simplidigitatus (Gad 2003). In particular, species III has a lorica consisting of plicae (Fig. 9, e.1) and, in this, resembles Pliciloricidae species more. This resemblance points to a plesiomorphic status within the Nanaloricidae.

There are similarities between the postlarvae of $P$. simplidigitatus and Armorloricus sp. I, but their Higginslarvae are quite different, as are those of Nanaloricus.

As a new species representing a new genus, the postlarva of $P$. simplidigitatus is characterized by the following features:

1. Lorica divided into ten plates

2. Lorica spikes small, 13 in number, with short gland ducts and reservoirs

3. First row of basal plates large, consisting of triangular plates

4. Posterior half of lorica with 18 papillate flosculi

5. Large, shield-like and overlapping anal plate.

Inhabited sediment and adaptations

The different taxa of Loricifera show adaptations and preferences for particular types of sediments. Nanaloricids seem to be confined to coarse, calcareous, sand-like shell gravel in shallow water habitats (Todaro and Kristensen 1998; Gad 2003) and show assumed adaptations to this habitat:

1. All of their life stages (adults, postlarvae and larvae) are extremely small even for Loricifera standards

2. The body is well armoured with lorica plates to prevent damage from moving sand grains

3. Well-developed adhesive structures are present (Kristensen 1991b; Kristensen and Gad 2003).

The adults have many pores on the lorica plates which are connected with subcuticular glands, whereas larvae have ventral grasping structures on the introvert and lorica, and additional adhesive glands at the base of their toes. Nanaloricidae, like other animals of the interstitial meiofauna (Gerlach 1977; Westheide 1991), seem to be widely distributed along the coasts and their restriction to coarse sands led to the assumption that they cannot 
disperse across fine-grained clayish bottoms of the deep sea.

Two new species of Nanaloricidae have recently been found in an oceanic habitat: on the plateau of the Great Meteor Seamount (Gad 2003). This plateau, which is covered with coarse calcareous sand is like a 'littoral habitat' (Gad and Schminke 2003) and, despite the isolation caused by a permanent circular current and by fine-grained clayish sediments in the surrounding deep sea harbours, an astonishingly diverse interstitial meiofauna with partly high Loricifera abundance ( Gad 2003; $\mathrm{Gad}$ and Schminke 2003). Among the more than 300 specimens of Loricifera found in 26 samples, only four belong to the Nanaloricidae. This implies a rather accidental colonisation of the plateau of the Great Meteor Seamount by this shallow-water faunal element. But it also indicates that Nanaloricidae are able to disperse widely across the oceans to colonize suitable interstitial habitats. In four series of deep-sea samples taken from (1) the Clarion-Clipperton fracture zone, NE Pacific (IOM BIE, RV 'Yuzhmorgeolgiya', 1995); (2) south Atlantic deep sea basins (ANT-XIII/5, RV 'Polarstern', 1996); (3) Angola Basin, E Atlantic (DIVA1, M48/1, RV 'Meteor', 2000); and (4) Antarctica (ANDEEP, ANT-XIX/3/4, RV 'Polarstern', 2002), new species of the known genera Pliciloricus and Rugiloricus, and of many new taxa also related to the Pliciloricidae have been found (Gad 2001). Enough data have been collected to point out that the finegrained clayish sediments of the deep sea have their own, characteristic Lorcifera fauna, which normally does not include representatives of Nanaloricidae. Therefore the species described here is an exception.

To explain this single find, the following arguments could be advanced:

1. The find is accidental and the new species normally lives in a littoral habitat around islands or on seamounts in the vicinity of the area where it was found

2. The substrate is not the normal, soft deep-sea sediment, but a mixture suitable for interstitial meiofauna

3. The species is an aberrant representative of Nanaloricidae showing its own adaptations to the deep-sea environment.

At first sight, the first argument may have some plausibility, but it is difficult to discuss, because nearly nothing is known about Loricifera from the Pacific, neither from the area around the sampling site nor from the Pacific as a whole. The only record from the Pacific and the deep sea is Pliciloricus hadalis (Kristensen and Shirayama 1988).

The second argument may be more promising. Despite the wide occurrence of fine-grained clayish sediments in the deep sea, there are hard substrates and other sediments similar to sand in coarseness and grain structure. Hydrothermal vents in the vicinity of the sampling area with rock outcrops, mineral crusts and bathymodiolid mussel banks may offer suitable conditions, although they are not known as a habitat for interstitial meiofauna (Giere 1993; Decraemer and Gourbault 1997; Vanreusel et al. 1997). There are coldwater coral formations at depths of between 40 and 1,200 m extending along suboceanic ridge systems and continental shelves in the Atlantic as well as in the Pacific (Freiwald 1998, 2003; Freiwald and Wilson1998). These formations are much larger than all tropical coral reefs in shallow water and may harbour a rich, unknown meiofauna. In particular, species of Epsilonematidae, which have frequently been found to inhabit similar habitats to Nanaloricidae, have been discovered at high densities in these deep-sea coral reefs (Raes et al. 2003).

Another example of the surprising discovery of shallow-water taxa in the deep sea is the discovery of the first representative of the Glochinematinae at a bathyal depth in the Peruvian trench. This new species was found to live at high densities exclusively in the upper layer of muddy sediment (Neira et al. 2001). Glochinematinae are usually an element of the interstitial meiofauna, especially common in sheltered beaches (Lorenzen 1974; Decraemer et al. 2001; Gad 2002). Glochinema bathyperuvensis Neira, Gad, Arroyo and Decraemer, 2001 from the oxygen minimum zone at $305 \mathrm{~m}$ depth does not seem to inhabit pure mud as first believed because of the soupy consistence of sediment in the samples. This may be an artefact of fixation. In this zone, there is a thick layer of round, permanent pellets of unknown origin, partly interspersed with colonies of giant sulphur bacteria. This natural structure of the sediment may have collapsed through fixation, transport and extraction of the meiofauna. This helps to understand why a species of Glochinema, otherwise known only from the interstitial of coarse sand, was found in this sediment. Its structure is not unlike sand, despite its completely different origins.

It is generally agreed that grain size, oxygen content and food availability are responsible for the structure of meiofauna communities and the presence of particular taxa or species (Higgins and Thiel 1988; Giere 1993). The sediment in which $P$. simplidigitatus sp. nov. was found is quite different from the characteristic fine-grained, clayish deep-sea bottoms. The upper $2 \mathrm{~cm}$ of the sediment of sample 63 GKG is composed of shells of Foraminifera, fractions of volcanic ashes and tiny basaltic pepperites with a very low percentage of fine organic material (Herzig 1998). Its coarseness (Giere 1993) should offer enough space for interstitial meiofauna, so that the occurrence of a species of Nanaloricidae is not necessarily accidental.

The argument would become even more convincing if the sample contained other meiofauna taxa otherwise known only from interstitial habitats. In the case of the Harpacticoida (Willen, personal communication), 117 specimens representing 27 species have been found in sample $63 \mathrm{GKG}$, which has a volume of $160 \mathrm{~cm}^{3}$. Most Harpacticoida belong to taxa with a wide occurrence in the deep sea on soft sediments, e.g. representatives of the 
Argestidae, Cerviniidae, Cletodidae and Pseudotachidiidae. Exceptions are a species of Canuellina Gurney, 1927 and a new species of Tetragonicipitidae. These taxa are otherwise known mainly from subtidal or littoral interstitial habitats (Willen, personal communication). Among the Nematoda, the Draconematidae are known to be characteristic of subtidal or littoral interstitial habitats (Allen and Noffsinger 1978). But in sample 63 GKG there was also a species of the genus Dracograllus Allen and Noffsinger, 1978, together with typical deep-sea species of the genera Dinetia Decraemer and Gourbault, 1997 and Cephalocheatosoma Kito, 1983 (Kito 1983; Decraemer and Gourbault 1997). In summary, it can be said that $P$. simplidigitatus sp. nov. was not the only potential inhabitant of the interstitial in sample number 63 GKG: there were others among the Harpacticoida and Nematoda, but even all of them together were the clear minority.

The third argument, referring to the morphology of the new species, is not easy to discuss, because the study of Loricifera is still in its early stages and only a few species are known. However, the postlarva, and as a consequence the adults, are not different from other species of Nanaloricidae in morphology. Only the Higgins-larva of $P$. simplidigitatus $\mathrm{sp}$. nov. has some morphological specialisations also found in Higgins-larvae of Pliciloricidae, which are widely distributed in fine-grained, clayish bottoms in the deep sea. The toes of $P$. simplidigitatus are spinose and simple, without a mucros, and equipped with a single pore at the base of the spine tip. The mucros of the larvae of other species of Nanaloricidae is said to play a role in locomotion (Kristensen 1983, 1991a), but it may also function as an enlarged surface for attachment to sand grains. The two large adhesive glands of the toes, which occupy the posterior half of the abdomen, seems to release an adhesive secretion out of many small pores in the enlarged toe bases (Kristensen 1991b). The ventral appendages of the trunk and the assumed grasping structures of the introvert are clearly less developed in the Higgins-larva of $P$. simplidigitatus than in other Nanaloricidae larvae. In particular, the long anterolateral appendages seem to fulfil a more sensory function, rather than grasping or locomotion, as has been said of Nanaloricidae Higgins-larva (Kristensen 1991a, 2003), because they are filiform and covered with fine setules. Many Pliciloricidae Higgins-larvae discovered in the deep sea have many flosculi in all body regions (Gad, personal observation). These small sensory organs (Kristensen 1991b) are generally associated with pores of subcuticular glands. The Higgins-larva of $P$. simplidigitatus has a higher number and even more conspicuous flosculi than other Nanaloricidae larvae. It also lacks the mouth cone and associated structures, a feature which is also common in many last instar larvae of Pliciloricidae, which also reduce toes and sensory setae. This reduction, common only in the last larval instar, is widespread in deep sea species (Gad 2001) and may also be an indication of adaptation in the larva of $P$. simplidigitatus.
Acknowledgements I thank Prof. H.K. Schminke for helpful comments and discussions. Thanks are also due to Dr. B. Neuhaus, Dr. F. Pardos and Prof. R.M. Kristensen for critical reading of the manuscript. Thanks to Dr. M. Türkay and Dr. T. Jellinek (Forschungsinstitut und Naturkundemuseum Senckenberg, Abteilung Zoologie II) who took the samples during the cruise SO-133 EDISON II to the New Ireland Basin, and to Dr. Elke Willen who studied the Harpacticoida. This work was supported by a grant from the Universitäts-Gesellschaft e.V. (Kongreß-Stipendienprogramm der Oldenburger Bankleiter) and from the Deutsche Forschungsgemeinschaft DFG (SCHM-352/31-1).

\section{References}

Allen MW, Noffsinger EM (1978) A revision of the marine nematodes of the superfamily Draconematoidae Filipjev, 1918 (Nematoda). Univ Calif Publ Zool 109

Brown PA (1997) A review of techniques used in the preparation, curation and conservation of microscope slides at the Natural History Museum, London. Biol Curator 10 [Suppl]

Decraemer W, Gourbault N (1997) Deep-sea nematodes (Nemata, Prochaetosomatinae): new taxa from hydrothermal vents and a polymetallic nodule formation of the Pacific (East Rise: North Fiji and Lau Bassins; Clarion-Cipperton fracture zone). Zool Scr 26:1-12

Decraemer W, Gourbault N, Helléouet M-N (2001) Cosmopolitanism among nematodes examples from Epsilonematidae. Vie Milieu 51:11-19

Freiwald A (1998) Modern nearshore cold-temperate calcareous sediments in the Troms District, northern Norway. J Sediment Res Sect A 68:763-776

Freiwald A (2003) Korallengärten in kalten Tiefen. Spektrum Wiss 2:56-63

Freiwald A, Wilson JB (1998) Taphonomy of modern deep, coldtemperate water coral reefs. Hist Biol 13:37-52

Gad G (2001) Die Tiefsee als Fundgrube neuer Loricifera Taxa. Terra Nostra 01/6:34

Gad G (2002) The relation between habitus and habitat structure as evidenced by a new species of Glochinema (Nematoda, Epsilonematidae) from the plateau of the Great Meteor Seamount. Hydrobiologia 474:171-182

Gad G (2003) The Loricifera fauna of the plateau of the Great Meteor Seamount. Arch Fish Mar Res (in press)

Gad G, Schminke HK (2003) How important are seamounts for the dispersal of meiofauna? Arch Fish Mar Res (in press)

Gerlach SA (1977) Means of meiofauna dispersal. In: Sterrer W, Ax $\mathrm{P}$ (eds) The meiofauna species in time and space. Mikrofauna Meeresboden 61:89-103

Giere O (1993) Meiobenthology - the microscopic fauna in aquatic sediments. Springer, Berlin Heidelberg New York

Grassle JF (1986) The ecology of deep-sea hydrothermal vent communities. Adv Mar Biol 23:301-363

Herzig PM (1998) Cruise report 'SONNE-133' (BMBF FK 03G0133A) volcanism, hydrothermal processes and biological communities at shallow submarine volcanoes of the New Ireland Fore-Arc (Papua New Guniea). Technische Universität Bergakademie, Freiberg, Germany

Higgins RP, Kristensen RM (1986) New Loricifera from southeastern United States coastal waters. Smithson Contrib Zool 438:1-70

Higgins RP, Kristensen RM (1988) Loricifera. In: Higgins RP, Thiel $\mathrm{H}$ (eds) Introduction to the study of meiofauna. Smithsonian Institution Press, Washington, DC

Higgins RP, Thiel H (eds) (1988) Introduction to the study of meiofauna. Smithsonian Institution Press, Washington, DC

Hubbard GF, Howard RL, Gallaway BJ (1988) Loricifera, a recently described phylum, occurring in the northern Gulf of Mexico. Northeast Gulf Sci 10:49-50

Kito K (1983) Deep-sea nematodes off Mindanao Island, the Phillippines-I Draconematidae. Annot Zool Jpn 56:27-41 
Kristensen RM (1983) Loricifera, a new phylum with Aschelminthes characters from the meiobenthos. Z Zool Syst Evolutionsforsch 21:163-180

Kristensen RM (1991a) Loricifera-a general biological und phylogenetic overview. Verh Dtsch Zool Ges 84:231-246

Kristensen RM (1991b) Loricifera. In: Harrison FW (ed) Aschelminthes, microscopic anatomy of invertebrates, vol 4. WileyLiss, New York, pp 351-375

Kristensen RM (2003) Loricifera. In: Hofrichter R (ed) Das Mittelmeer-Fauna, Flora, Ökologie, vol II/1 Bestimmungsführer. Spektrum, Heidelberg, pp 638-645

Kristensen RM, Brooke S (2002) Phylum Loricifera. In: Young CM (ed) Atlas of marine invertebrate larvae. Academic Press, San Diego, pp 179-187

Kristensen RM, Gad G (2003) Armorloricus a new genus of Loricifera (Nanaloricidae) from Trezen ar Skoden (Roscoff, France). Cah Biol Mar (in press)

Kristensen RM, Shirayama Y (1988) Pliciloricus hadalis (Pliciloricidae), a new loriciferan species collected from the IzuOgasawara Trench. West Pacif Zool Sci 5:875-881

Lorenzen S (1974) Glochinema nov. gen. (Nematodes, Epsilonematidae) aus Südchile. Mikrofauna Meeresboden 47:393-412
Neira C, Gad G, Arroyo NL, Decraemer W (2001) Glochinema bathyperuvensis sp. $\mathrm{n}$. (Nematoda, Epsilonematidae) a new species from Peruvian bathyal sediments, SE Pacific Ocean. Contrib Zool 70:147-159

Raes M, Vanreusel A, Decraemer W (2003) Epsilonematidae (Nematoda) associated with the cold-water coral Lophelia pertusa (Linneaus, 1758), with a discussion on the status of the genus Metaglochinema Gourbault and Decraemer, 1986. Hydrobiologia (in press)

Soetaert K, Heip C, Vincx M (1984) Meiofauna of the deep-sea transect off Corsica. Ann Soc R Zool Belg 114:323-324

Todaro MA, Kristensen RM (1998) A new species und first report of the genus Nanaloricus (Loricifera, Nanaloricidae) from the Mediterranean Sea. Ital J Zool 65:219-226

Vanreusel A, Bossche I van den, Thiermann F (1997) Free-living marine nematodes from hydrothermal sediments: similarities with communities from diverse reduced habitats. Mar Ecol Prog Ser 157:207-219

Westheide W (1991) The meiofauna of the Galápagos-a review. In: James MJ (ed) Galápagos marine invertebrates (taxonomy, biogeography and evolution in Darwin's islands). Plenum Press, New York, pp 37-69 